\section{Dismantling and rebuilding the food system after COVID-19: Ten principles for redistribution and regeneration}

\author{
Dana James ${ }^{a} *$ and Evan Bowness $\mathrm{b} * \neq$ \\ The University of British Columbia \\ Tabitha Robin ${ }^{\mathrm{c} *}$ \\ The University of Manitoba
}

Angela McIntyre ${ }^{\mathrm{d}}$ and Colin Dring e

The University of British Columbia

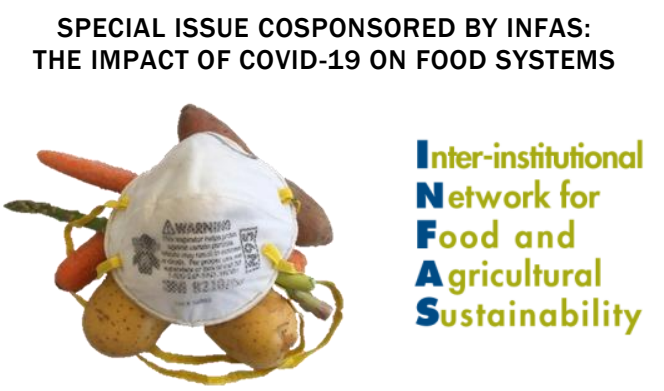

Annette Aurélie Desmarais ${ }^{\mathrm{f}}$

The University of Manitoba

Hannah Wittman $g$

The University of British Columbia

Submitted July 29, 2020 / Revised September 21 and October 8, 2020 / Accepted October 8, 2020 /

Published online February 7, 2021

Citation: James, D., Bowness, E., Robin, T., McIntyre, A., Dring, C., Desmarais, A. A., \& Wittman, H. (2021). Dismantling

and rebuilding the food system after COVID-19: Ten principles for redistribution and regeneration. Journal of Agriculture,

Food Systems, and Community Development, 10(2), 29-51. https://doi.org/10.5304/jafscd.2021.102.019

Copyright (C) 2021 by the Authors. Published by the Lyson Center for Civic Agriculture and Food Systems. Open access under CC-BY license.

\begin{abstract}
The COVID-19 pandemic has claimed hundreds of thousands of lives and cost economies trillions of dollars. Yet state responses have done little to address the negative externalities of the corporate
\end{abstract}

* Authors contributed equally.

${ }^{a}$ Dana James is a $\mathrm{PhD}$ candidate and Vanier Scholar, Institute for Resources, Environment and Sustainability (IRES) and the Centre for Sustainable Food Systems at UBC Farm (CSFS), The University of British Columbia. Dana.James@ubc.ca

$\mathrm{b} \ddagger$ Corresponding author: Evan Bowness is a PhD candidate, IRES and CSFS at The University of British Columbia. Evan.Bowness@gmail.com

${ }^{\mathrm{c}}$ Tabitha Robin (Martens) is a mixed ancestry Cree researcher, educator, and writer; PhD student, Faculty of Social Work and the Department of Native Studies, The University of Manitoba.Tabitha.Martens@umanitoba.ca

d Angela McIntyre is Associate Director at the Centre for Collaborative Action on Indigenous Health Research at Simon Fraser University. Angela.mcintyre@sfu.ca food regime, which has contributed to, and exacerbated, the impacts of the pandemic. In this paper, we build on calls from the grassroots for

${ }^{\mathrm{e}}$ Colin Dring is a PhD candidate, Integrated Studies in Land and Food Systems, The University of British Columbia. ColinD@mail.ubc.ca

f Annette Aurélie Desmarais is Canada Research Chair in Human Rights, Social Justice and Food Sovereignty, The University of Manitoba. Annette.Desmarais@umanitoba.ca

g Hannah Wittman is a Professor, IRES and the Faculty of Land and Food Systems The University of British Columbia. Hannah.Wittman@,ubc.ca

\section{Author Note}

This paper is an output of the collaborative and interdisciplinary Working Group on Redistribution for Food Systems Transformation. A previous draft was discussed during a Virtual Roundtable on September 18, 2020, as part of the Future of Food Global Dialogue Series at UBC.

\section{Funding Disclosure}

This working group is supported by the Peter Wall Institute for Advanced Studies at the University of British Columbia. 
states to undertake a strategic dismantling of the corporate food regime through redistributive policies and actions across scales, financed through reparations by key actors in the corporate food regime. We present a strategic policy framework drawn from the food sovereignty movement, outlined here as the "5Ds of Redistribution": Decolonization, Decarbonization, Diversification, Democratization, and Decommodification. We then consider what would need to occur postredistribution to ensure that the corporate food regime does not re-emerge, and pose five guiding principles grounded in Indigenous food sovereignty to rebuild regenerative food systems, outlined here as the " 5 Rs of Regeneration": Relationality, Respect, Reciprocity, Responsibility, and Rights. Together these ten principles for redistribution and regeneration provide a framework for food systems transformation after COVID-19.

\section{Keywords}

Corporate Food Regime, COVID-19, Food Sovereignty, Food Systems Transformation, Redistribution, Regeneration, Reparations

\section{Introduction}

At the time of writing, COVID-19 had claimed over two million human lives, with estimates by the Centre for Risk Studies that it will cause GDP losses of up to US\$82 trillion over the next five years (University of Cambridge Judge Business School, 2020). The magnitude of the pandemic has spurred an unprecedented response from governments: Trillions in fiscal emergency measures are set to drive up national deficits in the name of economic recovery (International Monetary Fund [IMF], 2020). As one example, the Canadian federal government allocated CA $\$ 169$ billion in emergency funds between March and June 2020 (Parliamentary Budget Officer, 2020), equivalent to more than 40\% of federal revenues in 2018-2019 (Government of Canada, 2019). Nevertheless, state responses fail to address the underlying structural features of the "corporate food regime" (McMichael, 2005), including land consolidation, industrialized and intensive crop and livestock production, the concentrated market power of multinational corporate actors, the tight coupling of the fossil energy and agri-food sectors, and liberalized global trade (Holt-Giménez \& Shattuck, 2011). Together, these features increase the risk of pandemics and exacerbate their effects (Wallace, Liebman, Chaves, \& Wallace, 2020).

Not only is the global corporate food regime highly implicated in and vulnerable to shocks like COVID-19 (Hendrickson, 2020), but it has long been described as an "international public health disaster" (Olivier De Schutter, cited in UN News, 2012, para. 4). Currently COVID-19 is exacerbating conditions such as food insecurity (World Food Programme, 2020), poor mental health (Torales, O'Higgins, Castaldelli-Maia, \& Ventriglio, 2020), and substance abuse (Holloway et al., 2020), while interacting with other ongoing pandemics that disproportionately affect people in the Global South, such as HIV/AIDS (McLinden, Stover, \& Hogg, 2020; Pérez-Escamilla, Cunningham, \& Moran, 2020). Like the $2009 \mathrm{H} 1 \mathrm{~N} 1$ influenza pandemic, COVID-19 follows health gradients, bringing higher infection risk and death rates to the lower socio-economic strata of highly unequal societies (Bambra, Riordan, Ford, \& Matthews, 2020; Jordan, Adab, \& Cheng, 2020).

In Canada and other high-income countries, risks of food insecurity and diet-related disease are elevated among those with low incomes (McIntyre, Bartoo, \& Emery, 2014; Phipps, Burton, Osberg, \& Lethbridge, 2006) and among Indigenous, Black, and other racialized populations (Batal et al., 2018; Damman, Eide, \& Kuhnlein, 2008; Domingo et al., 2020; McIntyre et al., 2014; Tarasuk \& Mitchell, 2020) who face geographic, social, cultural, and economic barriers to accessing healthy food. The loss of jobs and income as a result of COVID-19 has increased food insecurity in Canada (Holland, 2020; Statistics Canada, 2020), as well as globally (World Food Programme, 2020). Early analyses of COVID-19 mortality indicate that those with dietrelated diseases, such as cardiovascular diseases and type 2 diabetes, are at higher risk of morbidity and mortality due to COVID-19 (Bansal, 2020; Cariou et al., 2020; Hussain, Bhowmik, \& do Vale Moreira, 2020; Jordan et al., 2020; Stefan, Birkenfeld, Schulze, \& Ludwig, 2020). Higher consumption of ultra-processed foods in low-income communities, linked to malnutrition in the form of obesity, may 
be an underlying factor in higher COVID-19 death rates (White, Nieto, \& Barquera, 2020).

These findings suggest that the existing disparities created or deepened by the corporate food regime are now further exacerbated by worsening food insecurity, poverty, and health risks associated with COVID-19. Current state responses to this crisis appear compensatory, with the intention of stabilizing - not restructuring - the (food) economy. In Canada, for example, over CA $\$ 60$ million has been allocated by the federal government to Food Banks Canada alone (Food Banks Canada, 2020). While a necessary interim emergency response, in the words of Graham Riches, food banks nevertheless "prop up a broken system" in which overproduction and waste are inherent features that benefit corporations while undermining the human right to food and dignity (Riches, 2020). As another example, both the federal government and various provincial governments have declared meat processing an essential service, resulting in meat processing plants reopening after only short closures due to COVID-19 outbreaks in their facilities — some of the largest outbreaks in Canada-which put workers' lives at risk (Baum, Tait, \& Grant, 2020). As with previous economic recessions and crises, re-entrenchment of the status quo is thus the dominant expectation across political and economic institutions (see, for example, Wright [2010] on the push to "stimulate' the economy" and HLPE [2020] on investments after the 2007-2008 crisis).

Yet times of crisis provide opportunities for transformation (Wright, 2010). In this paper, using the pandemic response in Canada as an illustrative example, we consider possible policy responses to the global pandemic and their potential effects on building the food systems of the future, prioritizing the dimensions of our analysis by focusing on those responses most advocated by community and Indigenous organizations associated with the food sovereignty movement. Potential responses fall primarily into two categories. The first is reinvestment in the corporate food regime, thereby reproducing vulnerabilities, inequities, and the associated high costs to the environment, economy, human health, and overall well-being (IPESFood, 2017). A second, alternative pathway would be to transition purposefully to a more resilient and equitable food system by disrupting the processes which fuel the corporate food regime: Ongoing colonization and racism, industrialization, consolidation, concentration, and commodification. Following the lead of social movements oriented by food sovereignty principles, we echo calls for a strategic dismantling of the corporate food regime in order to create spaces for rebuilding food systems based on social justice and ecological foundations. Such a change requires economic and political restructuring through a suite of redistributive policies and actions across scales, following principles outlined here as the "5Ds of Redistribution": Decolonization, Decarbonization, Diversification, Democratization, and Decommodification. ${ }^{1}$ It also requires a complementary framework, which we have synthesized from Indigenous food sovereignty scholarship as the "5Rs of Regeneration": Relationality, Respect, Reciprocity, Responsibilities, and Rights.

While there is much debate about the role of the state in food sovereignty construction (RomanAlcalá, 2018, 2020; Schiavoni, 2017; Trauger, 2014; Trauger, Claeys, \& Desmarais, 2017), states must take on the role of dismantling the corporate food regime in accordance with the calls of the grassroots food sovereignty movement, because "only the state has the authority to mobilise state resources," expropriate and redistribute assets from large companies or landowners, and compel compliance (Borras, Franco, \& Suárez, 2015, p. 612). In their current configurations, however, (neo)liberal states alone are inadequate for reorganizing and rebuilding the democratic decision-making and governance systems central to food sovereignty (Trauger, 2014). Similarly, the International Monetary Fund and World Bank-imposed structural adjustment programs are prime examples of how misallocated power and control of intergovernmental institutions over the food economy can effectively undermine food security and exacerbate

\footnotetext{
${ }^{1}$ While others have used similar approaches to naming principles, which remarkably all begin with the letter D (Leach et al., 2020; Stirling, 2009), our proposal diverges somewhat from these and also expands the list.
} 
poverty (McMichael, 2005, 2014). Thus, it is insufficient to focus only on the role of state power in dismantling the corporate food regime, as such action does not preclude a return to, or reentrenchment of, the corporate food regime. In other words, while the state can play a necessary role in taking down the corporate food regime by redistributing power and resources, rebuilding alternatives entails mobilizing transdisciplinary knowledge and diverse actors to develop and implement policies for food security and sustainability (MacRae, 1999).

\section{Outline and Approach}

This conceptual article is organized into two main sections. In Part 1, we identify five principles, the 5Ds of Redistribution, which can guide redistributive policy directions for food systems transformation. We provide justification for the principles and examples of potential policy directions for redistribution proposed by social movements and proponents of food sovereignty in the Canadian context. In Part 2, we suggest a second, complementary set of principles, the 5Rs of Regeneration, drawn from the Indigenous food sovereignty literature and movements, to inform the rebuilding and governance of resilient food systems.

The 10 Principles for Redistribution and Regeneration conceptual framework emerged through discussions in a collaborative and interdisciplinary working group following the sudden and dramatic societal disruption caused by the COVID-19 crisis. As a group, we followed media coverage and reporting on the economic impacts of COVID-19, tracked unfolding state responses at a time when there was considerable uncertainty about how the pandemic would spread and its potential impact on the food system, and analyzed early social movement responses. The 5Ds are particularly informed by the latter, as the author collective-all community-engaged researchershas years of involvement and experience with land, food, and social justice movements. Two of our collective's members are Indigenous scholars actively involved with Indigenous food sovereignty organizations and struggles; three are white settler scholars; and two are racialized settler scholars, one of whom is queer. Collectively, we work with Indigenous communities, activist networks, community service and charitable organizations, different levels of government, and farmer organizations in North America/Turtle Island, ${ }^{2}$ South America, and subSaharan Africa. While the framework presented here does not represent the position of any individual food sovereignty organization, it is based on the demands of the global food sovereignty movement and links critical academic concepts to the political demands of some of the key movements involved in food systems transformation in Canada. The 5Rs are also informed by Kirkness and Barnhardt's (1991) foundational work on higher education for First Nations peoples, and the later work of Indigenous scholars sharing insights from Indigenous research methodologies (Hart, 2010; Kovach, 2009; Morrison, 2011; Wilson, 2008).

\section{Part 1. Dismantling Processes of Accumulation: The 5Ds of Redistribution}

In settler colonial states, economic growth is bound up in capitalist and colonialist processes of dispossession. In Canada, these processes include the clearing of lands for settlement, agricultural intensification and expansion, and extractive industries such as clearcut logging, mining, hydropower development, and fossil fuel extraction (Kepkiewicz \& Dale, 2018; Morrison \& Wittman, 2017; Willow, 2016). Extractivism has direct, negative impacts on health through toxic contamination, resource depletion, and landscape alterations that make Indigenous food systems inaccessible. These impacts disproportionately affect communities of color through the environmentally racist distribution of risks and benefits (Waldron, 2018) and can lead to Indigenous Peoples' over-reliance on market-based foods due to concerns around the safety and availability of traditional foods (Robin, Dennis, \& Hart, 2020; Waziyatawin, 2012). The COVID-19 pandemic and associated economic crisis are likely to intensify the struggles between marginalized communities, particularly Indigenous communities, and extractive industries (Bernauer \& Slowey, 2020).

\footnotetext{
2 Turtle Island is the name used by many Indigenous Peoples for what is usually referred to as North America.
} 
The corporate food regime-consisting of agribusiness, oil and gas, and other extractive industries including forestry, commercial fisheries, and associated technology and finance sectorshas therefore played a major role in colonizing, commodifying, and controlling lands and resources with an increasing carbon footprint, leading up to the COVID-19 pandemic. This has led to the corporate concentration of wealth and power in both the Canadian and global food system (Clapp, 2018; Holt-Giménez \& Shattuck, 2011; McMichael, 2005) while leaving individuals, communities, and states with diminishing control and influence (Fuchs \& Clapp, 2009). Yet transnational corporations are often difficult to hold accountable for their role in multiple health and socioecological crises (Bowness et al., 2021), including epidemics and pandemics (Wallace, 2016), toxic chemical exposure (Burger \& Bellon, 2020; Elver \& Tuncak, 2017; Shattuck, 2020), and biodiversity loss and climate change (Campbell et al., 2017). This is in part due to the obscuring effects—or mental and geographic "distance"-introduced by industrialization, globalization, and financialization (Clapp, 2014, 2015; Goodman \& Redclift, 1991; Goodman \& Watts, 1997; Kneen, 2002).

The disproportionate power exercised by transnational agri-food corporations and the social, economic, and ecological costs of the corporate food regime spurred the emergence of the global food sovereignty movement. The food sovereignty movement demands a radical shift from the corporate food regime toward more ecologically sustainable, resilient, equitable, and rights-based food systems that provide healthy food, are culturally appropriate, and support dignified livelihoods for food providers (Nyéléni Forum for Food Sovereignty, 2007). In response to the COVID-19 crisis, La Vía Campesina, one of the main international actors in the food sovereignty movement, has called for "solidarity across movements and borders" to collectively "demand that our governments channel resources to those that need them most" (La Via Campesina, 2020, para. 6).

The profound societal transformation advocated by the food sovereignty movement requires a mass mobilization of political will and resources. In the current liberalized and globalized economy, such a transformation necessitates international coordination and cooperation among states and social movements to curb the global influence of transnational corporations and to hold them to account. As Borras, Franco, and Suárez suggest, "all states and international organisations must respect and protect existing land-based social relationships in other countries and effectively regulate [transnational corporations (TNCs)] and business enterprises, the international financial system and the trade and investment regime accordingly" (2015, p. 612).

How should such a large-scale, foodsovereignty-inspired transformation be funded? One model in line with the status quo would follow the current organizing principle of the corporate food regime, "privatizing profits and socializing losses," which translates to the public shouldering the cost. However, an inverse model would finance the transition through reparations provided by the main beneficiaries of the corporate food regime-among them, large agri-food corporations, financial institutions, and states themselves -in accordance with the centuries of externalized costs that already have been borne by people and ecosystems. In accordance with a reparations-based approach, a transformation guided by the food sovereignty paradigm entails large-scale, statemediated redistribution of land, power, and wealth from the corporate food regime, based on the $5 \mathrm{D}$ principles: Decolonization, Decarbonization, Diversification, Democratization, and Decommodification. We describe these principles and their application to the Canadian context below.

\section{Decolonization}

Our approach to decolonization is explicitly anticolonial—emphasizing anti-racism, anti-sexism, and antiheteronormativity - with the understanding that white supremacy and settler colonialism are not events of the past but ongoing processes and structures (Wolfe, 2006). Agriculture in particular has historically been used to dispossess Indigenous Peoples, and this legacy persists today (Carter, 2019; Daschuk, 2019). In addition, infectious diseases and their specific effects on Indigenous Peoples have been a defining feature of Canada's colonial history (see, for example, the 
work of Carlson [1997] on the smallpox epidemic and Boggild, Yuan, Low, and McGeer [2011] on the disproportionate effect that H1N1 had on Indigenous people in 2009). With respect to COVID-19 in particular, Indigenous people are once again poised to be especially hard-hit due to the social determinants of health, rooted in ongoing colonialism, that structurally place them at high risk, e. g., food and water insecurity, crowded housing, jurisdictional challenges (Domingo et al., 2020; Levi \& Robin, 2020; Rice et al., 2016; Skye, 2020). Despite these considerations, only CA $\$ 305$ million, or $0.003 \%$ of the Canadian government's initial COVID-19 funding package, was allocated to Indigenous communities (Pasternak \& Houle, 2020). This massive underinvestment maintains the state's colonial approach to Indigenous-crown relations:

If a population indicator was utilized for the distribution of government relief, the allocation to First Nations would equal just over [CA] $\$ 4$ billion. [The reality is] a stark reminder on how government support and relief do not follow usual conventions when applied to First Nations and their communities. (Pasternak \& Houle, 2020, para. 13)
To move toward decolonizing the food system, grassroots Indigenous movements, food sovereignty organizations, and scholars of settler colonialism emphasize that policies must be implemented that redistribute land and wealth to Indigenous Peoples (Table 1). Decolonization is context-dependent, and accordingly will take different forms in different places. Just as colonization is both mental and material-perpetuated by ongoing land dispossession and the extractivism on which settler states depend-decolonization is also mental and material. Following other Indigenous and settler scholars (Smith, 2012; Tuck \& Yang, 2012), we view decolonization as involving not only the cultivation of a critical consciousness, but also material redistribution. In settler colonial contexts such as Canada, where land has been violently and unjustly coerced or stolen from Indigenous Peoples, and where these patterns continue to be reproduced through state and capitalist expansion of the extractive economy and state exertions of sovereignty, decolonization necessitates Indigenous self-determination and "must involve the repatriation of land simultaneous to the recognition of how land and relations to land have always already been differently understood and enacted" (Tuck \& Yang, 2012, p. 7). Indeed, while there is enormous diversity within and across Indigenous communi-

Table 1. Examples of Redistributive Policies Supporting Decolonization

\begin{tabular}{|c|c|c|c|}
\hline \multicolumn{4}{|c|}{ Decolonization } \\
\hline Redirect / Redistribute & What & From & To \\
\hline \multirow{2}{*}{$\begin{array}{l}\text { Processes of redistribution } \\
\text { and redirection }\end{array}$} & Land & \multirow{2}{*}{ The state and property owners } & \multirow{2}{*}{ Indigenous communities } \\
\hline & Wealth & & \\
\hline $\begin{array}{l}\text { Example policy } \\
\text { recommendations from the } \\
\text { Canadian context }\end{array}$ & $\begin{array}{l}\text { - Expedite res } \\
\text { Indigenous a } \\
\text { - } \text { Return land } \\
\text { with Crown la } \\
\text { - } \text { Deliver on tre } \\
\text { including hor } \\
\text { Boisselle, 20 } \\
\text { Nations, } 201 \\
\text { - } \text { Decrease re } \\
\text { Kanatami, 2 } \\
\text { - Negotiate an } \\
\text { demands (M } \\
\text { - Guarantee tr } \\
\text { to food (De S }\end{array}$ & $\begin{array}{l}\text { f existing and future land claims } \\
\text { ern Affairs, 2018). } \\
\text { diction to Indigenous Peoples (P } \\
\text { ple's Food Policy Project, 2011). } \\
\text { gations (Manuel \& Derrickson, } 2 \\
\text { nd continually negotiating mech } \\
\text { ording to a pre-doctrine of discov } \\
\text { barriers to traditional food harve } \\
\text { rrison, 2008). } \\
\text { e reparations in accordance witr } \\
\text { Derrickson, 2015). } \\
\text { o clean water (Lukawiecki, Plotk } \\
\text { 2012). }\end{array}$ & $\begin{array}{l}\text { nding Committee on } \\
\text { rnak \& King, 2019), beginning } \\
\text { Starblanket \& Hunt, 2020), } \\
\text { ms of sharing (Scott \& } \\
\text { ramework (Assembly of First } \\
\text { and processing (Inuit Tapiriit } \\
\text { h Indigenous Nation's specific } \\
\text { Boisvert, 2018) and the right }\end{array}$ \\
\hline
\end{tabular}


ties, many Indigenous food sovereignty scholars and advocates describe land as kin and food as sacred, informed by a relational worldview that recognises the interdependence of human and nonhuman nature (Coté, 2016; Morrison \& Wittman, 2017).

\section{Decarbonization}

There is scientific consensus that the world must cut emissions dramatically to avoid catastrophic climate disruption. Globally, the agriculture and food sector is among the largest contributors to greenhouse gas (GHG) emissions (Campbell et al., 2017; IPCC, 2019). In Canada, the agriculture sector alone contributes almost $10 \%$ of Canadian emissions (Government of Canada, 2020b). Canada ranks eleventh globally in production of greenhouse gas emissions (Government of Canada, 2020a) and is one of the world's highest per capita GHG emitters (Stoddart, Tindall, \& Greenfield, 2012). Despite committing in the Paris Agreement to reduce its GHG emissions to 30\% below 2005 levels by 2030, even in the most optimistic scenario Canada is projected to miss its reduction target of 304 megatons by 77 megatons of carbon dioxide equivalent (Environment and Climate Change Canada, 2019).

In line with the degrowth paradigm (Gerber, 2020), decarbonization requires moving beyond the reproduction of industrial relations in efforts to reduce emissions by entirely reconfiguring economies in a way that is socially just and respects ecological limits. We use the term decarbonization here in a broad sense, to refer to the need to cut all greenhouse gases and toxic emissions, while noting that carbon-based extraction in particular is driving major climate disruption, with significant effects on the food system. In addition, the industrial food system-itself highly dependent on fossil fuels and a key driver of land use change-causes significant harm to ecosystems and the planet as a whole (Campbell et al., 2017).

Decarbonizing the food system requires states to enact policies that redirect capital flows away from fossil energy-intensive agri-food sector enterprises to low fossil energy-intensive enterprises, in the pursuit of net zero emissions (Table 2). Farmer organizations in the food sovereignty movement have already identified strategies and policy options to reduce agricultural emissions in Canada while simultaneously improving farmer and worker livelihoods and public health. One option, for example, is for the state to "tax shift" by heavily taxing resource-intensive, high-emission companies and redistributing funds to food providers and workers (Qualman \& National Farmers Union, 2019). Additionally, the state could subsidize lowemission agroecological systems and research for communities most affected by climate change, both domestically and in the Global South.

Beyond the GHG emissions intensity of agriculture and food production, it is worth acknowledging the downstream aspects of the food system that are carbon intensive: diet (Tilman \& Clark, 2014; Willett et al., 2019) and food waste (Cuéllar \& Webber, 2010; Scialabba, 2015). Decarboniza-

Table 2. Examples of Redistributive Policies Supporting Decarbonization

\begin{tabular}{|c|c|c|c|}
\hline \multicolumn{4}{|c|}{ Decarbonization } \\
\hline Redirect / Redistribute & What & From & To \\
\hline \multirow{2}{*}{$\begin{array}{l}\text { Processes of redistribution } \\
\text { and redirection }\end{array}$} & Profits and subsidies & Energy-intensive firms & Low-energy enterprises \\
\hline & Wealth (intra- and interstate) & $\begin{array}{c}\text { The biggest GHG-emitting } \\
\text { states }\end{array}$ & $\begin{array}{l}\text { Regions most affected by } \\
\text { climate change }\end{array}$ \\
\hline $\begin{array}{l}\text { Example policy } \\
\text { recommendations from the } \\
\text { Canadian context }\end{array}$ & $\begin{array}{l}\text { - Redirect subsidies from fos } \\
\text { development and low emis } \\
\text { National Farmers Union, 2 } \\
\text {-Just transition" policies th } \\
\text { workers in fossil-energy int } \\
\text { decarbonization (Cooling, L } \\
\text { - Provide reparations to low- } \\
\text { debt, and open borders to }\end{array}$ & $\begin{array}{l}\text { il fuel and agricultural input } \\
\text { ons technology and farming } \\
\text { 19; see also MacRae et al., } 2 \\
\text { t provide a green jobs guara } \\
\text { nsive industries at risk of dis } \\
\text { e, Daub, \& Singer, 2015). } \\
\text { nd middle-income countries } \\
\text { imate refugees (Dickson, We }\end{array}$ & $\begin{array}{l}\text { porations to clean energy } \\
\text { D, 2019; Qualman and } \\
\text { 3). } \\
\text { e and retraining programs for } \\
\text { cement during } \\
\text { line with Canada's climate } \\
\text { er, \& Takaro, 2014). }\end{array}$ \\
\hline
\end{tabular}


tion of the food system would therefore also entail a shift to less GHG-intensive diets and reductions in food waste. Both features of the food system were highlighted during the COVID-19 crisis: meatpacking plant workers were forced to continue to work in dangerous conditions to meet the demand for meat, while plant closures reduced processing capacity and forced the euthanasia of animals ready for market, fueling waste. This was a missed opportunity to implement a just transition for meatpacking workers and undertake a concerted policy effort to incentivize the production and distribution of less GHG-intensive foods. In addition, the fact that supply chain disruptions and restaurant closures led to food losses for farmers while simultaneously demand at food banks was spiking (Dyer, 2020; Harvey, 2020) should prompt a rethinking of how to structure and mediate food markets and expand food preservation and nutrient recovery programs to decrease hunger, food waste, and GHG emissions across the food system.

\section{Diversification}

Generally, diversification in the Canadian agricultural policy context means producing different crops for integration into the global market. Here, we employ the concept of diversification to directly challenge biological, sociocultural, and political homogenization. Canada is a highly exportoriented agricultural powerhouse (Agriculture and Agri-Food Canada, 2017); globally, it is the fifthlargest exporter of agri-food products (Government of Canada, 2016). More than half of the value of Canada's agricultural production is sold for consumption abroad (Government of Canada, 2016). Nevertheless, Canada is also one of the world's largest agri-food importers; it is particularly dependent on the U.S., with $60 \%$ of the value of Canada's agri-food imports attributed to the U.S. in 2016 (Agriculture and Agri-Food Canada, 2017). In addition, certain agri-food sectors in Canada are highly concentrated. The export-oriented meat sector is a case in point: just three plants (two owned by Cargill and one by JBS) are responsible for $80-95 \%$ of Canadian beef processing (Fedor, 2020; National Farmers Union, 2020). As COVID19 has demonstrated, such an extreme level of concentration in the supply chain(s) creates bottlenecks that are vulnerable to disruption and underscore the need for a more diversified food system.

Redistributive policies in line with the diversification principle aim to redress specialization and homogenization in the food system (Nyström et al., 2019), in terms of what is grown and eaten, and in terms of how food is processed and distributed (Table 3). Redistribution should thus aim to increase diversity in at least two ways: increasing agrobiodiversity at multiple scales (Intergovernmental Science-Policy Platform on Biodiversity and Ecosystem Services, 2019; International Panel of Experts on Sustainable Food Systems, 2016), and creating new, diverse, and territorially embedded food supply chains (MacRae, 2011). For example, Canada could take steps to strengthen and enforce competition laws at home to lessen the power that highly concentrated agri-food corporations have

Table 3. Examples of Redistributive Policies Supporting Diversification

\begin{tabular}{|c|c|c|c|}
\hline \multicolumn{4}{|c|}{ Diversification } \\
\hline Redirect / Redistribute & What & From & To \\
\hline \multirow{2}{*}{$\begin{array}{l}\text { Processes of redistribution } \\
\text { and redirection }\end{array}$} & Subsidies and land & $\begin{array}{l}\text { Large-scale farmers of } \\
\text { monoculture commodities }\end{array}$ & $\begin{array}{l}\text { Small- to medium-scale } \\
\text { agroecological food providers }\end{array}$ \\
\hline & Profits and corporate equity & $\begin{array}{l}\text { Large centralized } \\
\text { processors, distributors, } \\
\text { and retailers }\end{array}$ & $\begin{array}{l}\text { Small regional processors, } \\
\text { distributors, and retailers }\end{array}$ \\
\hline $\begin{array}{l}\text { Example policy } \\
\text { recommendations from the } \\
\text { Canadian context }\end{array}$ & \multicolumn{3}{|c|}{  } \\
\hline
\end{tabular}


over determining product availability on market shelves. However, these competition laws should be layered with fair trade considerations to ensure not only accountability and transparency for growers and consumers in Canada, but also provisions for farmer and worker welfare abroad, especially in low-income countries (De Schutter, 2010).

\section{Democratization}

In the most basic sense, democratization refers to creating more equitable access to decision-making power-especially for those who have been disenfranchised, marginalized, and/or excluded from democratic processes (Levkoe \& Sheedy, 2019) — in a context of transparency. As such, our interpretation of democratization is not statecentric; it includes those who live in Canada but are not formally recognized as citizens, including migrant food and agricultural workers and refugees, who are often disproportionately impacted by food insecurity (Lane, Nisbet, \& Vatanparast, 2019; Weiler, McLaughlin, \& Cole, 2017) and the effects of COVID-19 (Haley et al., 2020).

Both progressive and radical strategies (HoltGiménez \& Shattuck, 2011) are needed to democratize and decentralize food system governance and redistribute decision-making power. A reconfiguration of state institutions could break down government silos through more horizontal governance, and dissolve overly bureaucratic and exclusionary decision-making processes through participatory and transdisciplinary engagement (Andrée, Coulas, \& Ballamingie, 2018; MacRae, 1999, 2011)—for example, by creating food policy councils at multiple jurisdictional levels and heeding their recommendations, and by respecting nation-to-nation agreements (People's Food Policy Project, 2011).

Beyond the state, democratization also requires expanding and transforming oversight of agri-food corporations and companies whose operations incur significant costs to the public in the form of health, social, and environmental externalities (MacRae \& Winfield, 2016; Wittman, 2015) (Table 4). As more than three thousand scholars recently asserted in a call to action in The Guardian (Fraser et al., 2020), the nature of work and workplaces must be democratized. For example, the Canadian government could require agri-food businesses to transition towards worker-owned models in order to receive COVID-related support (Fraser et al., 2020). This would provide food workers, including migrant workers, increased control over their own health, labor, and futures. The democratization of work prioritizes progressive labor law reforms that encourage and enhance unionization, in contrast to the regressive labor laws that have accompanied the rise and concentration of corporate power under neoliberalism (Ferdosi, 2020; Riddell, 2004).

\section{Table 4. Examples of Redistributive Policies for Democratization}

\begin{tabular}{|c|c|c|c|}
\hline \multicolumn{4}{|c|}{ Democratization } \\
\hline Redirect / Redistribute & What & From & To \\
\hline \multirow{2}{*}{$\begin{array}{l}\text { Processes of redistribution } \\
\text { and redirection }\end{array}$} & Control over government & $\begin{array}{l}\text { Corporate lobbies and } \\
\text { political and economic elites }\end{array}$ & People \\
\hline & $\begin{array}{c}\text { Control over corporate } \\
\text { entities }\end{array}$ & Owners and executives & Workers \\
\hline $\begin{array}{l}\text { Example policy } \\
\text { recommendations from the } \\
\text { Canadian context }\end{array}$ & $\begin{array}{l}\text { - Make government fundin } \\
\text { - } \text { Reoperatives (Fraser et a } \\
\text { private sector (Schenk, } 2 \\
\text { - Provide migrant workers } \\
\text { provide pathways to citize } \\
\text { - Employ a governance mo } \\
\text { pluralism (Koc, MacRae, } \\
\text { equitable and “joined-up' } \\
\text { 2016). }\end{array}$ & $\begin{array}{l}\text { and support contingent upon } \\
\text {, and enact policies that enco } \\
14 \text { ). } \\
\text { esident status on arrival and o } \\
\text { nship (Migrant Rights Network } \\
\text { del based on legal (Scott \& Boi } \\
\text { Jesjardins, \& Roberts, 2008) t } \\
\text { food and land policies (MacR }\end{array}$ & $\begin{array}{l}\text { nsitioning to worker } \\
\text { onization in the } \\
\text { permits, and } \\
\text { 19) and regulatory } \\
\text { Marticipatory, } \\
\text { MacRae \& Winfield, }\end{array}$ \\
\hline
\end{tabular}




\section{Decommodification}

The right to food has been established through a number of international agreements and covenants, including the Universal Declaration of Human Rights (UDHR) and the International Covenant on Economic, Social and Cultural Rights (ICESCR). Despite its "commitment to the progressive realization of the right to food" (Rideout, Riches, Ostry, Buckingham, \& MacRae, 2007, p. 566), the Canadian government has yet to guarantee this right in practice. COVID-19 has exacerbated food insecurity-not a new problem in the Canadian context, particularly for marginalized populations-reinvigorating discussions on the commodification of food versus rights-based approaches to addressing food insecurity.

Redistributive policies should directly address the inequitable effects of enclosure, generally referring to the disruption of common management regimes through the creation of property amenable to private ownership. Neoliberal market policy has allowed some actors to accumulate a disproportionate share of property and profit, leading to a concentration of land and other resources, and thus wealth and power (Borras et al., 2015; Hendrickson, Howard, \& Constance, 2019). Policies aimed at decommodification interrupt capital accumulation by re-designating key components in the food system-land, food, and labor in particular-as basic rights (with associated responsibilities), rather than property that can be exploited for profit.

To properly compensate for the augmented cost of production from internalizing social and ecological costs, some food prices may need to increase. This requires that members of the public also see their purchasing power increase. A reparations-oriented redistributive perspective on the trend towards corporate concentration in the food system points to the need to explore policies that would redistribute wealth, land, and corporate profits and equity to the economically marginalized among farmers, workers, and eaters (Table 5). This could be accomplished through taxation and regulation. For example, the state could implement a universal basic income program as an interim step in the progressive realization of the right to food, while establishing progressive corporate tax regimes and a progressive wealth tax to subsidize social welfare programs and strengthen social safety nets.

\section{Part 2. Rebuilding from the Bottom Up: The 5Rs of Regeneration}

Following the dismantling of the corporate food regime through redistribution, what would need to occur so that it cannot re-emerge? What could a regenerative food regime look like?

We highlight five guiding principles as the $5 \mathrm{Rs}$ of Regeneration," rooted in the work of Indige-

Table 5. Examples of Redistributive Policies for Decommodification

\begin{tabular}{|c|c|c|c|}
\hline \multicolumn{4}{|c|}{ Decommodification } \\
\hline Redirect / Redistribute & What & From & To \\
\hline \multirow{3}{*}{$\begin{array}{l}\text { Processes of redistribution } \\
\text { and redirection }\end{array}$} & Income, property, and wealth & Economic elites & Economically marginalized \\
\hline & Land & $\begin{array}{l}\text { States and corporate } \\
\text { land holders }\end{array}$ & $\begin{array}{l}\text { Indigenous Peoples, } \\
\text { agroecological farmers, } \\
\text { the public }\end{array}$ \\
\hline & Profits and corporate equity & Corporations & Workers \\
\hline $\begin{array}{l}\text { Example policy } \\
\text { recommendations from } \\
\text { the Canadian context }\end{array}$ & $\begin{array}{l}\text { - Redistribute wealth through } \\
\text { - Provide a guaranteed basic } \\
\text { - } \text { cocial safety nets (Himelfar } \\
\text { - Hamilton, 2005; Wittman, } \\
\text { marginalized populations. } \\
\text { - Legally enshrine the right to } \\
\text { for building food sovereignt } \\
\text { 2017). }\end{array}$ & $\begin{array}{l}\text { x reform (Macdonald, } 2 \\
\text { come (Alston, 2017; Tar } \\
\text { Hennessy, 2016). } \\
\text { and small-scale food pI } \\
\text { inis \& Pritchard, 2017), } \\
\text { od and other rights-bas } \\
\text { ood Secure Canada \& L }\end{array}$ & $\begin{array}{l}\text { 2018). } \\
\text { 2017) while strengthening } \\
\text { ers (Gorsuch \& Scott, 2010; } \\
\text { priority to historically } \\
\text { cial protections necessary } \\
\text { ek, 2017; Lambek et al., }\end{array}$ \\
\hline
\end{tabular}


nous food sovereignty scholars and advocates (Martens, Cidro, Hart, \& McLachlan, 2016; Morrison, 2011, 2008), to rebuild resilient and vibrant land and food systems post-redistribution: Relationality, Respect, Reciprocity, Responsibility, and Rights. Given that the 5Rs are rooted in Indigenous research methodologies (Hart, 2010; Kovach, 2009; Wilson, 2008) and Indigenous approaches to education in Canada (Kirkness \& Barnhardt, 1991), and represent traditional Indigenous values, ${ }^{3}$ this section is presented through an Indigenous epistemology of interconnectedness, with the understanding that these principles are cyclical. We flesh out the 5Rs with on-the-ground examples from interstitial spaces in Canada, or "the niches, spaces and margins of capitalist society" (Wright, 2010, p. 211).

\section{Relationality}

Relationality is both an ontological and epistemological concept (Wilson, 2008) 4 that opens up new possibilities for (co)existence (Andreotti, Ahenakew, \& Cooper, 2012). Because Indigenous Peoples understand the world through processes of relating to living and nonliving beings, ways of knowing are contextual and based on specific observations and experiences across time (Deloria, 2003), capturing the dynamic and interconnected nature of place-based realities.

In practice, relationality includes gratitude. Acts of gratitude in a just food system require protecting the land by advocating for clean water, air, and soil (Martens, 2018). In a globalized world, the concept of relationality also speaks to the need to situate knowledge and harmonize Canada's governance efforts by "[enabling] other countries to develop food systems with similar purposes and values" (MacRae, 2011, p. 433) in the pursuit of planetary health (Whitmee et al., 2015).

The Indigenous principle of "seven generations" sheds light on the significance of relationality (it has been seven generations since Canada's foundational Indian Act of 1876). This is a concept in many Indigenous cultures that considers ancestral, present, and future generations in actions toward the land. Applying the seven generations framework (see, for example, Borrows, 2008) emphasizes that care, stewardship, and systemic approaches are necessary to ensure that the land will be healthy and treated with respect. In Canada, examples of wholesystems and relational approaches to food and wellness can already be found in some Indigenous communities where social services incorporate land and food-based programming as preventative and holistic endeavors that bring people together in healing (see, for example, the Nisichawayasihk Cree Nation Family and Community Wellness Centre [Nisichawayasihk Cree Nation, 2018]). Another example is the People's Food Policy Project, which engaged around 3,500 participants in a collaborative consultation process over three years to create a vision for a coherent and systematic national food policy (Levkoe \& Sheedy, 2019; People’s Food Policy Project, 2011).

\section{Respect}

In many prairie-based Indigenous cultures in Canada, respect is taught through the seven sacred teachings: wisdom, love, respect, bravery, humility, honesty, and truth (Borrows, 2008, p. 11). For example, the bison-considered a sacred and keystone species, whose loss is still felt in communities today - carries the teaching of respect through its life-giving abilities (Robin et al., 2020). Traditionally, all parts of the bison were used; thus, to waste life is to disrespect the gifts provided through creation. To enact respect for the living world entails honoring the gifts of life and the relationships that exist between and among all living and nonliving beings (Kimmerer, 2013).

A respectful food system is anti-colonial and anti-oppressive. It requires people and institutions to consider the impacts and interconnectedness of capitalism, colonialism, racism, patriarchy, and other forms of oppression in the food system. Importantly, it also requires people and institutions

\footnotetext{
${ }^{3}$ We do not intend to pan-Indigenize; rather, we mean only to highlight some of the "shared aspects" of an Indigenous ontology, epistemology, and axiology as described by Wilson (2008, p. 7).

${ }^{4}$ Ontology and epistemology are interrelated concepts typically used in philosophy. Ontology is concerned with the nature of reality(ies) and the world. Epistemology has to do with the nature of knowledge(s) and ways of knowing.
} 
to seek action through both social reform and land protection. Enacting the principle of respect necessitates a deliberate reconsideration of unsustainable and inequitable actions in relation to the land and human and non-human actors. For example, a respectful food system precludes the possibility of worker and animal exploitation and abuse- problems that have been made ever more visible as a result of COVID-19 (Graveland, 2020; Haley et al., 2020).

Perhaps one of the most pertinent examples of a deeply disrespectful food system that has arisen during the COVID-19 pandemic is the demeaning approach of relying on food banks to feed people. While providing critical services, the reputation of food banks as "dumping grounds" for less desirable food is deeply concerning (Robin et al., 2020). In contrast, respectful food governance requires a dignified way to distribute food; indeed, on-theground examples can already be found in places where communities take on the work of feeding their members. In Indigenous communities in Canada, this is visible through the maintenance of country foods programs in which hunters, fishers, and gatherers are compensated for stocking a community freezer; fresh traditional food is then distributed to community members (NMFCCC, 2017). Scholars have also noted the holistic approach to food security used by some food hubs that explicitly move beyond emergency food assistance and toward more democratic projects of community self-determination (Figueroa, 2015; Levkoe, 2017), as well as by self-organized grassroots efforts to redistribute food directly (RomanAlcalá, 2020).

\section{Reciprocity}

A food system based on respect for people and nature is reciprocal; give-and-take practices are in constant operation. Through Indigenous ways of knowing, being, seeing, and doing, reciprocity is critical to maintaining and supporting respectful relationships and to understanding the sacredness of the gifts of life, including food. The principle of reciprocity could help guide the creation of a new form of social and economic governance based on equitable and caring exchanges, which have already emerged in response to COVID-19 in the form of mutual aid initiatives in Canada (Mutual Aid Network Canada, 2020) and across the world (RomanAlcalá, 2020).

A just and sustainable food system requires active participation by those in relationship with the land, who adhere to processes of giving back. For example, to consume fish means to be in relationship with the water. Reciprocity in this relationship must also include gratitude expressed by caring for water through research, policy, and/or advocacy work, and by guaranteeing access to clean water for all communities, including Indigenous communities, in perpetuity (Martens, 2018). To ensure that water is not misused (i.e., through continued privatization, contamination, and depletion), scholars and advocates have identified the need to develop a holistic and coordinated multi-jurisdictional water strategy, embedded in broader hydrosocial relations which recognize both the human right to water and the responsibility for the care of water (Barlow, 2016, 2019; Wilson, Harris, Joseph-Rear, Beaumont, \& Satterfield, 2019).

\section{Responsibility}

Indigenous people come to understand roles and responsibilities through the teachings of their Nations. For example, naming and clan systemsan ancestral kinship system that honors animal beings - are a mechanism through which responsibilities are ascribed to Indigenous people in their interdependent relationships with creation. To live responsibly means to carry out the individual, family and community roles and obligations that have been gifted through ancestral teaching and responsibilities. Teachings refer, inter alia, to the scientific and cultural knowledge of lands and places, accumulated since time immemorial, embodied in Indigenous languages and enacted in daily practices (Cote, 2016).

The principle of responsibility provides accountability to those relationships that are important: with one another, and to the life-giving ecosystems on which we depend. In practice, responsibility towards the land and its inhabitants requires direct action through relationship; taking responsibility seriously requires policy-makers, organizers, protectors, protestors, and advocates to consider how responsibility is enacted through 
relationship to the land (Wilson, 2008). For example, the mobilization of 'urban agrarians' who organize from cities in defense of distant foodlands and food providers points to a developing sense of responsibility for broader food systems change (Bowness \& Wittman, 2020). In transitioning to a regenerative food system, we have also suggested that those who have benefited most from the corporate food regime be held responsible for past harms, and should provide reparations accordingly.

\section{Rights}

Responsibilities go hand-in-hand with rights. Human rights, Indigenous and collective rights, and food providers' rights are established in treaties, covenants, and declarations signed by states at the international level, including the Universal Declaration of Human Rights (UDHR), the United Nations Declaration on the Rights of Indigenous Peoples (UNDRIP), and the United Nations Declaration on the Rights of Peasants and Other People Working in Rural Areas (UNDROP). The implementation of these rights is then enacted by states, local communities, and municipal or regional governments through legislation. For example, in late 2019 the British Columbia government passed the B.C. Declaration on the Rights of Indigenous Peoples Act in order to implement UNDRIP provincially (B.C. Government, 2019).

While rights instruments play an important role in addressing historical and ongoing state, corporate, and individual harms, we recognize that they may also reinforce problematic notions of state sovereignty. In the Canadian context, for example, the state is the authorizer and enforcer of human and Indigenous rights, which it fails to guarantee in practice. In a context where the state has attempted to assimilate Indigenous Peoples into colonial ways of being, attention must be paid to both the rights of individuals and the collective rights of Peoples (National Inquiry into Missing and Murdered Indigenous Women and Girls, 2019).

The pursuit of - and responsibility forupholding individual, Indigenous, collective, and, increasingly, nature's rights is at once universal and context-specific. As noted by the National Inquiry into Missing and Murdered Indigenous Women and Girls, distinguishing between forms of rightshuman, Indigenous, collective-is a means to reevaluate which rights should be protected by the state and which rights must be "upheld through new relationships and by confronting racism, discrimination, and stereotypes" (2019, p. 182). This expanded notion of rights departs from traditional Westphalian notions of rights and citizenship, which privilege the sovereignty of individual nation states. The increasing recognition of the "rights of nature" is one example that illustrates how the notion of rights has broadened beyond an anthropocentric focus (see, for example, the White Earth band of Ojibwe's Rights of Manoomin [LaDuke, 2019]).

These emerging notions of rights and citizenship still derive from states and their capacity to enact legislation that defines legal persons worthy of recognition and protection. However, as with broader conceptions of rights, such as those proposed by the food sovereignty movement (Wittman, 2009), collectivities are strategically reasserting and ascribing rights to food providers, lands, and waters. Regenerative food systems governance could expand not only which rights apply and to what and whom, but also the range of entities which have the capacity to grant them.

\section{Conclusion}

The COVID-19 crisis presents a renewed urgency to place food systems transformation at the front and centre of post-pandemic recovery plans. It has reminded the world of the essential nature of food, land, and workers, while shining a light onto some of the major environmental, economic, social, and health problems resulting from the profit-oriented corporate food regime and the vulnerabilities therein. Importantly, it has also demonstrated the capacity for states to mobilize and shift resources on a massive scale in times of crisis.

The COVID-19 pandemic is a wake-up call for states to find new ways to facilitate food system resilience and address the risks embedded within the highly specialized, concentrated, and exploitative food system. We argue that transforming food systems to become more resilient, sustainable, and just entails a process of both dismantling and rebuilding. The dismantling process could be facili- 
tated through the state-mediated redistribution of land, wealth, and power accrued by major actors in the corporate food regime in line with the food sovereignty principles of Decolonization, Decarbonization, Diversification, Democratization, and Decommodification. Following the calls that have emerged from grassroots Indigenous food sovereignty organizations in Canada, we then propose a different set of principles-Relationality, Respect, Reciprocity, Responsibility, and Rights - to counter the values embedded in neoliberal racial capitalism (such as privatization, competition, rationalization, etc.) and to guide the rebuilding of new food futures in ways that prevent the reemergence of exploitative, neoliberal food systems. While not exhaustive, the ten principles synthesized here offer a framework to guide and track research on the progress, barriers, and opportunities related to pursuing this radical transition.

While we have largely focused here on redistribution within the confines of national borders, the globally interconnected nature of food systems (in particular, the importance of international trade, the influence and reach of transnational corporations, and the rise of wicked problems such as climate change) means that national policies must be nested within internationally coordinated and harmonized global food policy frameworks. Establishing new and coherent forms of governance at multiple scales is another area that is ripe for future research by food systems scholars and practitioners.

For too long, the main actors in the corporate food regime have benefited from the externalization of social, health, and environmental costs and risks, which have in turn been borne by the public, and disproportionately so by structurally marginalized social groups. It is our hope that in taking stock of the current moment, policy-makers, leaders of social movements, and food sovereignty advocates can align policy responses in pursuit of a transformative food systems agenda. Redistribution is a necessary step to provide redress for the harms caused by the corporate food regime and to finance a just transition to more resilient, sustainable, and equitable food systems.

\section{Acknowledgments}

The authors would like to thank Dr. Jennifer Clapp and Sophia Murphy for their helpful comments on a prior version of this manuscript, as well as four anonymous JAFSCD reviewers for their encouraging and constructive feedback.

\section{References}

Agriculture and Agri-Food Canada. (2017). An overview of the Canadian agriculture and agri-food system 2017. Ottawa: Agriculture and Agri-Food Canada. https://ryancardwee.files.wordpress.com/2019/12/overview-2017.pdf

Alston, P. (2017). Report of the Special Rapporteur on extreme poverty and human rights on his mission to the United States of America. Geneva: United Nations Human Rights Office of the High Commissioner. https://www.ohchr.org/EN/NewsEvents/Pages/DisplayNews.aspx?NewsID=22533

Andrée, P., Coulas, M., \& Ballamingie, P. (2018). Governance recommendations from forty years of national food strategy development in Canada and beyond. Canadian Food Studies / La Revue Canadienne Des Études Sur l'alimentation, 5(3), 6-27. https://doi.org/10.15353/cfs-rcea.v5i3.283

Andreotti, V. de O., Ahenakew, C., \& Cooper, G. (2012). Equivocal knowing and elusive realities: Imagining global citizenship otherwise. In V. de O. Andreotti \& L. M. Souza (Eds.), Postcolonial perspectives on global citizenship education (pp. 221-238). New York, NY \& Abingdon, UK: Routledge. https://doi.org/10.4324/9780203156155

Assembly of First Nations. (2018). Dismantling the doctrine of discovery. Ottawa: Assembly of First Nations. https://www.afn.ca/wp-content/uploads/2018/02/18-01-22-Dismantling-the-Doctrine-of-Discovery-EN.pdf

Bambra, C., Riordan, R., Ford, J., \& Matthews, F. (2020). The COVID-19 pandemic and health inequalities. Journal of Epidemiology and Community Health, 74(11), 964-968. https://doi.org/10.1136/jech-2020-214401

Bansal, M. (2020). Cardiovascular disease and COVID-19. Diabetes \& Metabolic Syndrome: Clinical Research \& Reviews, 14(3), 247-250. https://doi.org/10.1016/j.dsx.2020.03.013

Barlow, M. (2016). Boiling point: Government neglect, corporate abuse, and Canada's water crisis. Toronto: ECW Press.

Barlow, M. (2019). Whose water is it, anyway? Taking water protection into public hands. Toronto: ECW Press. 
Batal, M., Johnson-Down, L., Moubarac, J. C., Ing, A., Fediuk, K., Sadik, T., ... Willows, N. (2018). Sociodemographic associations of the dietary proportion of ultra-processed foods in First Nations peoples in the Canadian provinces of British Columbia, Manitoba, Alberta and Ontario. International Journal of Food Sciences and Nutrition, 69(6), 753-761. https://doi.org/10.1080/09637486.2017.1412405

Baum, K. B., Tait, C., \& Grant, T. (May 2, 2020). How Cargill became the site of Canada's largest single outbreak of COVID-19. The Globe and Mail. https://www.theglobeandmail.com/business/article-how-cargill-became-the-siteof-canadas-largest-single-outbreak-of/

Bernauer, W., \& Slowey, G. (2020). COVID-19, extractive industries, and Indigenous communities in Canada: Notes towards a political economy research agenda. The Extractive Industries and Society, 7(3), 844-846. https://doi.org/10.1016/i.exis.2020.05.012

Boggild, A. K., Yuan, L., Low, D. E., \& McGeer, A. J. (2011). The impact of influenza on the Canadian First Nations. Canadian Journal of Public Health / Revue Canadienne de Santé Publique, 102(5), 345-348. https://doi.org/10.1007/BF03404174

Borras, S. M., Franco, J. C., \& Suárez, S. M. (2015). Land and food sovereignty. Third World Quarterly, 36(3), 600-617. https://doi.org/10.1080/01436597.2015.1029225

Borrows, J. (2008). Seven generations, seven teachings: Ending the Indian Act (Research paper). Ottawa: National Centre for First Nations Governance. https://www.saddlelakecreenation.ca/assets/ 7 generations 7 teachings.pdf

Bowness, * E., James, * D., Desmarais, A. A., McIntyre, A., Dring, C., Robin, T., \& Wittman, H. (2021). COVID-19 and the 'organized irresponsibility' of the corporate food regime. Studies in Political Economy: A Socialist Review. *Authors contributed equally. https://doi.org/10.1080/07078552.2020.1849986

Bowness, E., \& Wittman, H. (2020). Bringing the city to the country? Privilege, responsibility and urban agrarianism in Metro Vancouver. Journal of Peasant Studies. Advance online publication. https://doi.org/10.1080/03066150.2020.1803842

British Columbia Government. (2019). B.C. Declaration on the Rights of Indigenous Peoples Act. Victoria, BC: B.C. Government. https://www2.gov.bc.ca/gov/content/governments/indigenous-people/new-relationship/unitednations-declaration-on-the-rights-of-indigenous-peoples

Burger, L., \& Bellon, T. (2020, June 24). Bayer to pay up to $\$ 10.9$ billion to settle bulk of Roundup weedkiller cancer lawsuits. Reutters: Healthcare \& Pharma. Retrieved from https://www.reuters.com/article/us-bayer-litigationsettlement/bayer-to-pay-up-to-109-billion-to-settle-bulk-of-roundup-weedkiller-cancer-lawsuits-idUSKBN23V2NP

Campbell, B. M., Beare, D. J., Bennett, E. M., Hall-Spencer, J. M., Ingram, J. S. I., Jaramillo, F., ... Shindell, D. (2017). Agriculture production as a major driver of the Earth system exceeding planetary boundaries. Ecology and Society, 22(4), art. 8. https://doi.org/10.5751/ES-09595-220408

Cariou, B., Hadjadj, S., Wargny, M., Pichelin, M., Al-Salameh, A., Allix, I., ... Gourdy, P. (2020). Phenotypic characteristics and prognosis of inpatients with COVID-19 and diabetes: The CORONADO study. Diabetologia, 63, 1500-1515. https://doi.org/10.1007/s00125-020-05180-x

Carlson, K. T. (1997). First contact: Smallpox. In K. T. Carlson (Ed.) You are asked to witness: The Sto:lo in Canada's Pacific Coast history (pp. 27-40). Chilliwack, BC: Sto:lo Heritage Trust.

Carter, S. (2019). Lost harvests: Prairie Indian reserve farmers and government policy (Second ed.). Montreal: McGill-Queen's University Press.

Clapp, J. (2014). Financialization, distance and global food politics. Journal of Peasant Studies, 41(5), 797-814. https://doi.org/10.1080/03066150.2013.875536

Clapp, J. (2015). Distant agricultural landscapes. Sustainability Science, 10(2), 305-316. https://doi.org/10.1007/s11625-014-0278-0

Clapp, J. (2018). Mega-mergers on the menu: Corporate concentration and the politics of sustainability in the global food system. Global Environmental Politics, 18(2), 12-33. http://dx.doi.org/10.1162/glep a 00454

Cooling, K., Lee, M., Daub, S., \& Singer, J. (2015). Just transition: Creating a green social contract for BC's resource workers. Vancouver: Canadian Centre for Policy Alternatives, BC Office. https://www.policyalternatives.ca/publications/reports/just-transition 
Coté, C. (2016). "Indigenizing" food sovereignty. Revitalizing Indigenous food practices and ecological knowledges in Canada and the United States. Humanities, 5(3), 57. https://doi.org/10.3390/h5030057

Cuéllar, A. D., \& Webber, M. E. (2010). Wasted food, wasted energy: The embedded energy in food waste in the United States. Environmental Science \& Technology, 44(16), 6464-6469. https://doi.org/10.1021/es100310d

Damman, S., Eide, W. B., \& Kuhnlein, H. V. (2008). Indigenous peoples' nutrition transition in a right to food perspective. Food Policy, 33(2), 135-155. https://doi.org/10.1016/j.foodpol.2007.08.002

Daschuk, J. (2019). Clearing the plains: Disease, politics of starvation, and the loss of Indigenous life. Regina, SK: University of Regina Press.

De Schutter, O. (2010). Addressing concentration in food supply chains: The role of competition law in tackling the abuse of buyer power (Briefing note 03). Geneva: United Nations Human Rights Council. https://www.ohchr.org/Documents/Issues/Food/BN3 SRRTF Competition ENGLISH.pdf

De Schutter, O. (2012). Report of the Special Rapporteur on the right to food on his mission to Canada. Geneva: United Nations Human Rights Council. https://digitallibrary.un.org/record/742873

Deloria Jr., V. (2003). God is red: A Native view of religion (Third ed.). Golden, CO: Fulcrum.

Dickson, S., Webber, S., \& Takaro, T. K. (2014). Preparing BC for Climate Migration. Vancouver: Canadian Centre for Policy Alternatives, BC Office. http://www.policyalternatives.ca/sites/default/files/uploads/publications/BC\%20Office/2014/11/ccpabc ClimateMigration web.pdf

Domingo, A., Spiegel, J., Guhn, M., Wittman, H., Ing, A., Sadik, T., .. Batal, M. (2020). Predictors of household food insecurity and relationship with obesity in First Nations communities in British Columbia, Manitoba, Alberta and Ontario. Public Health Nutrition. Advance online publication. https://doi.org/10.1017/s1368980019004889

Dyer, E. (2020, May 6). The pandemic is creating a season of anxiety in hard-hit farm sectors. Ottawa: Canadian Broadcasting Corporation, News: Politics. Retrieved from https://www.cbc.ca/news/politics/agriculture-pandemic-covid-coronavirus-canada-1.5556670

Elver, H., \& Tuncak, B. (2017). Report of the Special Rapporteur on the right to food. Geneva: United Nations Human Rights Council. https://documents-dds-ny.un.org/doc/UNDOC/GEN/N17?224?73?PDF?N1722473.pdf?OpenElement

Environment and Climate Change Canada. (2019). Canadian environmental sustainability indicators: Progress towards Canada's greenhouse gas emissions reduction target. Gatineau, QC: ECCC. https://www.canada.ca/en/environment-climatechange/services/environmental- indicators/progress-towards-canada-greenhouse-gas-emissions-reductiontarget.html

Fedor, T. (2020, April 30). Cargill's reopening welcome news for ranchers. Calgary: CTV News Calgary.

Ferdosi, M. (2020). Canadian labour rights in crisis: The Harper years. Critique, 48(1), 13-29. https://doi.org/10.1080/03017605.2019.1706782

Figueroa, M. (2015). Food sovereignty in everyday life: Toward a people-centered approach to food systems. Globalizations, 12(4), 498-512. https://doi.org/10.1080/14747731.2015.1005966

Food Banks Canada. (2020). COVID-19 response fund donor accountability statement. Mississauga, ON: Food Banks Canada. https://www.foodbankscanada.ca/FoodBanks/MediaLibrary/Documents-Resources/2020/FBC-DonorAccountability-Statement-SEP4.pdf

Food Secure Canada, \& Lambek, N. (2017). aMontreal: FSC. https://foodsecurecanada.org/sites/foodsecurecanada.org/files/briefing notes right to food fsc5bigideas 07201 7 2.pdf

Fraser, N., Neiman, S., Mouffe, C., Sassen, S., Müller, J.-W., Rodrick, D., et al. (2020, May 15). Humans are not resources. Coronavirus shows why we must democratise work. The Guardian. https://www.theguardian.com/commentisfree/2020/may/15/humans-resources-coronavirus-democratise-workhealth-lives-market

Fuchs, D., \& Clapp, J. (2009). Corporate power and global agrifood governance: Lessons learned. In J. Clapp \& D. Fuchs (Eds.), Corporate power in global agrifood governance (pp. 285-296). Cambridge, MA: MIT Press.

Goodman, D., \& Redclift, M. (1991). Refashioning nature: Food, ecology and culture. Abingdon, UK \& New York: Routledge. 
Goodman, D., \& Watts, M. J. (1997). Globalising food: Agrarian questions and global restructuring. Abingdon, UK, \& New York: Routledge.

Gorsuch, W., \& Scott, R. (2010). A review of farmland trusts: Communities supporting farmland, farming, and farmers. Victoria, BC: The Land Conservancy of British Columbia, FarmFolk / CityFolk. https://foodsecurecanada.org/sites/foodsecurecanada.org/files/A review of farmland trusts.pdf

Government of Canada. (2016). An overview of the Canadian agriculture and agri-food system 2016. Ottawa: Government of Canada. https://www.agr.gc.ca/eng/about-our-department/publications/economic-publications/an-overview-ofthe-canadian-agriculture-and-agri-food-system-2016/?id=1462288050282\#a2

Government of Canada. (2019). Annual financial report of the Government of Canada Fiscal Year 2018-2019. Ottawa: Government of Canada. https://www.canada.ca/en/department-finance/services/publications/annual-financial-report/2019/report.html

Government of Canada. (2020a). Global greenhouse gas emissions. Ottawa: Government of Canada. https://www.canada.ca/en/environment-climate-change/services/environmental-indicators/global-greenhousegas-emissions.html

Government of Canada. (2020b). Greenhouse gas sources and sinks: Executive summary 2020. Ottawa: Government of Canada. https://www.canada.ca/en/environment-climate-change/services/climate-change/greenhouse-gasemissions/sources-sinks-executive-summary-2020.html

Graveland, B. (2020, May 8). Canada's beef and pork producers forced to consider culls as COVID-19 limits meat processors. The Globe and Mail. https://www.theglobeandmail.com/canada/article-canadas-beef-and-porkproducers-forced-to-consider-culls-as-covid-1/

Haley, E., Caxaj, S., George, G., Hennebry, J. L., Martell, E., \& McLaughlin, J. (2020). Migrant farmworkers face heightened vulnerabilities during COVID-19. Journal of Agriculture, Food Systems, and Community Development, 9(3), 35-39. https://doi.org/10.5304/jafscd.2020.093.016

Hamilton, B. B. (2005). Agricultural land trusts: Preserving small farm heritage. Winnipeg: Canadian Centre for Policy Alternatives, Manitoba Office. https://www.policyalternatives.ca/sites/default/files/uploads/publications/Manitoba Pubs/2005/Agricultural La nd Trusts.pdf

Hart, M. A. (2010). Indigenous worldviews, knowledge, and research: The development of an Indigenous research paradigm. Journal of Indigenous Voices in Social Work, 1(1), 1-16. http://hdl.handle.net/10125/15117

Harvey, A. (2020, April 11). Canadian food banks struggle to stay open, just as demand for their services skyrockets. The Globe and Mail. https://www.theglobeandmail.com/canada/toronto/article-canadian-food-banks-struggle-to-stayopen-just-as-demand-for-their/

Hendrickson, M. K. (2020). Covid lays bare the brittleness of a concentrated and consolidated food system. Agriculture and Human Values, 37, 579-580. https://doi.org/10.1007/s10460-020-10092-y

Hendrickson, M. K., Howard, P. H., \& Constance, D. H. (2019). Power, food, and agriculture: Implications for farmers, consumers, and communities. In J. W. Gibson \& S. E. Alexander (Eds.), In defense of farmers: The future of agriculture in the shadow of corporate power (pp. 13-61). Lincoln: University of Nebraska Press.

High Level Panel of Experts on Food Security and Nutrition (HLPE). (2020). Food security and nutrition: Building a global narrative towards 2030 (Summary of $15^{\text {th }}$ report). Rome: HLPE, Committee on World Food Security. http://www.fao.org/3/ca9733en/ca9733en.pdf

Himelfarb, A., \& Hennessy, T. (2016). Basic income-A way forward. In A. Himelfarb \& T. Hennessy (Eds.), Basic Income: Retbinking Social Policy (pp. 9-12). Toronto: Canadian Centre for Policy Alternatives, Ontario Office. https://www.policyalternatives.ca/publications/reports/basic-income

Holland, K. L. (2020). Canada's food security during the COVID-19 pandemic (SPP Research paper 13:13). Calgary, AB: University of Calgary, School of Public Policy. http://dx.doi.org/10.11575/sppp.v13i0.70350

Holloway, I. W., Spaulding, A. C., Ochoa, A. M., Randall, L. A., King, A. R., The HBOU Study Team, \& Frew, P. M. (2020). COVID-19 vulnerability among people who use drugs: Recommendations for global public health programmes and policies. Journal of the International AIDS Society, 23, 1-3. https://doi.org/10.1002/jia2.25551 
Holt-Giménez, E., \& Shattuck, A. (2011). Food crises, food regimes and food movements: Rumblings of reform or tides of transformation? Journal of Peasant Studies, 38(1), 109-144. https://doi.org/10.1080/03066150.2010.538578

Hussain, A., Bhowmik, B., \& do Vale Moreira, N. C. (2020). COVID-19 and diabetes: Knowledge in progress. Diabetes Research and Clinical Practice, 162, 108142. https://doi.org/10.1016/j.diabres.2020.108142

Intergovernmental Science-Policy Platform on Biodiversity and Ecosystem Services (IPBES). (2019). The global assessment report on biodiversity and ecosystem services. Summary for policymakers. Bonn: IPBES Secretariat. https://www.ipbes.net/sites/default/files/202002/ipbes global assessment report summary for policymakers en.pdf

Intergovernmental Panel on Climate Change (IPCC). (2019). Special report on climate change and land. Summary for policymakers. Geneva: IPCC. https://www.ipcc.ch/srccl/

International Institute for Sustainable Development. (2019). Submission to Environment and Climate Change Canada's Consultation on Non-Tax Fossil Fuel Subsidies. Winnipeg, MB: IISD. https://www.iisd.org/sites/default/files/publications/iisd-submission-eccc-non-tax-subsidies.pdf

International Monetary Fund [IMF]. (2020). Policy responses to COVID-19. Washington, DC: IMF. https://www.imf.org/en/Topics/imf-and-covid19/Policy-Responses-to-COVID-19

International Panel of Experts on Sustainable Food Systems (IPES-Food). (2016). From uniformity to diversity: A paradigm shift from industrial agriculture to diversified agroecological systems (Report 2). Brussels, Belgium: IPES-Food. https://www.ipes-food.org/ img/upload/files/UniformityToDiversity FULL.pdf

International Panel of Experts on Sustainable Food Systems (IPES-Food). (2017). Unravelling the food-health nexus: Addressing practices, political economy, and power relations to build healthier food systems. Executive summary. Brussels, Belgium: IPES-Food. https://www.ipes-food.org/ img/upload/files/Health ExecSummary(1).pdf

Inuit Tapiriit Kanatami. (2017). An Inuit-specific approach for the Canadian Food Policy. Ottawa: Inuit Tapiriit Kanatami. https://www.itk.ca/wp-content/uploads/2019/01/ITK Food-Policy-Report.pdf

Isaac, M. E., Isakson, S. R., Dale, B., Levkoe, C. Z., Hargreaves, S. K., Mendez, V. E., ... Ciani, A. G. (2018). Agroecology in Canada: Towards an integration of agroecological practice, movement and science. Sustainability, 10(9), 3299. https://doi.org/10.3390/su10093299

Jordan, R. E., Adab, P., \& Cheng, K. K. (2020). Covid-19: Risk factors for severe disease and death (Editorial). British Medical Journal, 368, m1198. https://doi.org/10.1136/bmj.m1198

Kimmerer, R. W. (2013). Braiding sweetgrass: Indigenous wisdom, scientific knowledge and the teachings of plants. Minneapolis, MN: Milkweed.

Kirkness, V. J., \& Barnhardt, R. (1991). First Nations and higher education: The four R's—respect, relevance, reciprocity, responsibility. Journal of American Indian Education, 30(3), 1-15.

Kneen, B. (2002). Invisible giant: Cargill and its transnational strategies (Second ed.). London, UK \& Sterling, VA: Pluto Press.

Koc, M., MacRae, R., Desjardins, E., \& Roberts, W. (2008). Getting civil about food: The interactions between civil society and the state to advance sustainable food systems in Canada. Journal of Hunger \& Environmental Nutrition, 3(2-3), 122-144. https://doi.org/10.1080/19320240802243175

Kovach, M. (2009). Indigenous methodologies: Characteristics, conversations, and contexts. Toronto: University of Toronto Press.

La Via Campesina. (2020, April 7). COVID-19—Small-scale food producers stand in solidarity and will fight to bring healthy food to all. International Planning Committee for Food Sovereignty (IPC) statement. https:/ / viacampesina.org/en/covid-19-small-scale-food-producers-stand-in-solidarity-and-will-fight-to-bringhealthy-food-to-all/

LaDuke, W. (2019, Feb. 21). The rights of wild rice. In These Times. https://inthesetimes.com/article/the-rights-of-wild-rice-winona-laduke-white-earth-rights-of-nature

Lambeck, N. C. S., Bronson, D., Farha, L., Neve, A., Porter, B., Riches, G., .. McLeod-Kilmurray, H. (2017). Ensuring the human right to food through A Food Policy for Canada: Submissions to the government of Canada. Montreal: Food Secure Canada. https://foodsecurecanada.org/sites/foodsecurecanada.org/files/attached files/right to food submissions on a food policy for canada.pdf 
Lane, G., Nisbet, C., \& Vatanparast, H. (2019). Food insecurity and nutritional risk among Canadian newcomer children in Saskatchewan. Nutrients, 11(8), 1744. https://doi.org/10.3390/nu11081744

Leach, M., Nisbett, N., Cabral, L., Harris, J., Hossain, N., \& Thompson, J. (2020). Food politics and development. World Development, 134, 105024. https://doi.org/10.1016/j.worlddev.2020.105024

Levi, E., \& Robin, T. (2020). COVID-19 did not cause food insecurity in Indigenous communities but it will make it worse. Toronto: Yellowhead Institute, Ryerson University. https://yellowheadinstitute.org/2020/04/29/covid19-food-insecurity/

Levkoe, C. Z. (2017). Communities of food practice: Regional networks as strategic tools for food systems transformation. In I. Knezevic, A. Blay-Palmer, C. Z. Levkoe, P. Mount, \& E. Nelson (Eds.), Nourishing communities: From fractured food systems to transformative pathways (pp. 183-200). London: Springer. https://doi.org/10.1007/978-3-319-57000-6

Levkoe, C. Z., \& Sheedy, A. (2019). A people-centred approach to food policy making: Lessons from Canada's People's Food Policy project. Journal of Hunger \& Environmental Nutrition, 14(3), 318-338. https://doi.org/10.1080/19320248.2017.1407724

Lukawiecki, J., Plotkin, R., \& Boisvert, A. (2018). Executive summary. Reconciling promises and reality: Clean drinking water for First Nations (Second annual report). Vancouver, BC: David Suzuki Foundation. https://davidsuzuki.org/wpcontent/uploads/2018/02/reconciling-promises-reality-clean-drinking-water-first-nations-SUMMARY.pdf

Macdonald, D. (2014). Outrageous fortune: Documenting Canada's wealth gap (Report). Ottawa: Canadian Centre for Policy Alternatives-National Office. https://www.policyalternatives.ca/outrageous-fortune

Macdonald, D. (2018). Born to win: Wealth concentration in Canada since 1999 (Report). Ottawa: Canadian Centre for Policy Alternatives-National Office. https://www.policyalternatives.ca/publications/reports/born-win

MacRae, R. (1999). Not just what, but how: Creating agricultural sustainability and food security by changing Canada's agricultural policy making process. Agriculture and Human Values, 16(2), 187-202. https://doi.org/10.1023/A:1007528823700

MacRae, R. (2011). A joined-up food policy for Canada. Journal of Hunger \& Environmental Nutrition, 6(4), $424-457$. https://doi.org/10.1080/19320248.2011.627297

MacRae, R., Cuddeford, V., Young, S. B., \& Matsubuchi-Shaw, M. (2013). The food system and climate change: An exploration of emerging strategies to reduce GHG emissions in Canada. Agroecology and Sustainable Food Systems, 37(8), 933-963. https://doi.org/10.1080/21683565.2013.774302

MacRae, R., \& Winfield, M. (2016). A little regulatory pluralism with your counter-hegemonic advocacy? Blending analytical frames to construct joined-up food policy in Canada. Canadian Food Studies / La Revue Canadienne Des Études Sur l'alimentation, 3(1), 140-194. https://canadianfoodstudies.uwaterloo.ca/index.php/cfs/article/view/60

Manuel, A., \& Derrickson, R. M. (2015). Unsettling Canada: A national wake-up call. Toronto: Between the Lines.

Manuel, A., \& Derrickson, R. (2017). The reconciliation manifesto: Recovering the land, rebuilding the economy. Toronto: James Lorimer.

Martens, T. R. (2018). Responsibilities and reflections: Indigenous food, culture, and relationships. Canadian Food Studies / La Revue Canadienne des Études sur l'alimentation, 5(2), 9-12. https://doi.org/10.15353/cfs-rcea.v5i2.216

Martens, T., Cidro, J., Hart, M. A., \& McLachlan, S. (2016). Understanding Indigenous food sovereignty through an Indigenous research paradigm. Journal of Indigenous Social Development, 5(1), 18-37. https://umanitoba.ca/faculties/social work/media/V5i1-02martens cidro hart mclachlan.pdf

McIntyre, L., Bartoo, A. C., \& Emery, J. C. H. (2014). When working is not enough: food insecurity in the Canadian labour force. Public Health Nutrition, 17(1), 49-57. https://doi.org/10.1017/S1368980012004053

McLinden, T., Stover, S., \& Hogg, R. S. (2020). HIV and food insecurity: A syndemic amid the COVID-19 pandemic. AIDS and Behavior, 24(10), 2766-2769. https://doi.org/10.1007/s10461-020-02904-3

McMichael, P. (2005). Global development and the corporate food regime. In F. H. Buttel \& P. McMichael (Eds.), New directions in the sociology of global development (Research in rural sociology and development, Vol. 11) (pp. 265-299). Bingley, UK: Emerald Group. https://doi.org/10.1016/S1057-1922(05)11010-5 
McMichael, P. (2014). Historicizing food sovereignty. Journal of Peasant Studies, 41(6), 933-957. https://doi.org/10.1080/03066150.2013.876999

Migrant Rights Network. (2020). Open letter. Full immigration status for all. Canada: Migrant Rights Network. http://www.StatusforAll.ca

Morrison, D. (2008). B.C. Food Systems Network Working Group on Indigenous food sovereignty. Final activity report. Nelson, BC: B.C. Food Systems Network, Working Group on Indigenous Food Sovereignty. https://foodsecurecanada.org/sites/foodsecurecanada.org/files/WGIFS $\% 20$ Final $\% 20$ Report $\% 202 \% 20$ March. $\% 20$ 08.pdf

Morrison, D. (2011). Indigenous food sovereignty—A model for social learning. In H. Wittman, N. Wiebe, \& A. A. Desmarais (Eds.), Food sovereignty in Canada: Creating just and sustainable food systems (pp. 97-113). Winnipeg, MB: Fernwood.

Morrison, D., \& Wittman, H. (2017). Indigenous land and food. In P. D. Tortell, M. Young, \& P. N. Nemetz (Eds.), Reflections of Canada: Illuminating our opportunities and challenges at 150+ years (pp. 130-138). Vancouver: Peter Wall Institute for Advanced Studies, University of British Columbia.

Mutual Aid Network Canada. (2020). COVID-19 community response networks (Canada). https://docs.google.com/document/d/1LsHkTBMS0YX 4F7OSAt55ppV0xICi50AXdF62vRw4W8/edit

National Farmers Union. (2020, April 22). Meat packing concentration makes Canada's food system vulnerable. Saskatoon, SK: NFU. https://www.nfu.ca/wp-content/uploads/2020/04/2020-04-21-Concentration-of-meatpacking-makes-Canada-vulnerable.pdf

National Inquiry into Missing and Murdered Indigenous Women and Girls. (2019). Reclaiming power and place: Executive summary of the Final Report. Ottawa: MMIWG. https://www.mmiwg-ffada.ca/final-report/

Nisichawayasihk Cree Nation. (2018). A holistic approach to community wellness. Nelson House, MB: Nisichawayasihk Cree Nation. https://www.ncnwellness.ca/page/2/

Northern Manitoba Food, Culture \& Community Collaborative (NMFCCC). (2017). Patbways for starting country foods programs. Winnipeg: NMFCCC.

http://www.nmfccc.ca/uploads/4/4/1/7/44170639/pathways for starting country foods programs.pdf

Nyéléni Forum for Food Sovereignty. (2007). Nyéléni declaration on food sovereignty. Nyéléni Village, Sélingué, Mali: La Via Campesina. https://nyeleni.org/spip.php?article290

Nyström, M., Jouffray, J. B., Norström, A. V., Crona, B., Søgaard Jørgensen, P., Carpenter, S. R., .. Folke, C. (2019). Anatomy and resilience of the global production ecosystem. Nature, 575, 98-108. https://doi.org/10.1038/s41586-019-1712-3

Parliamentary Budget Officer. (2020). COVID-19 Response Plan: Costings requested by parliamentarians. Ottawa: PBO. https://www.pbo-dpb.gc.ca/en/covid-19

Pasternak, S., \& Houle, R. (2020, April 9). No such thing as natural disasters: Infrastructure and the First Nation fight against COVID-19. Toronto: Yellowhead Institute, Ryerson University. https://yellowheadinstitute.org/2020/04/09/no-such-thing-as-natural-disasters-infrastructure-and-the-first-nationfight-against-covid-19/

Pasternak, S., \& King, H. (2019). Land back: A Yellowhead Institute Red Paper. Toronto: Yellowhead Institute, Ryerson University. https://redpaper.yellowheadinstitute.org/wp-content/uploads/2019/10/red-paper-report-final.pdf

People's Food Policy Project. (2011). Resetting the table: A people's food policy for Canada. Montreal: Food Secure Canada. https://foodsecurecanada.org/sites/foodsecurecanada.org/files/FSC-resetting2012-8half11-lowres-EN.pdf

Pérez-Escamilla, R., Cunningham, K., \& Moran, V. H. (2020, May 26). Covid-19 and maternal and child food and nutrition insecurity: A complex syndemic (Editorial). Maternal \& Child Nutrition, 16(3), e13036. https://doi.org/1.1111/mcn.13036

Phipps, S. A., Burton, P. S., Osberg, L. S., \& Lethbridge, L. N. (2006). Poverty and the extent of child obesity in Canada, Norway and the United States. Obesity Reviews, 7(1), 5-12. https://doi.org/10.1111/j.1467-789X.2006.00217.x

Qualman, D., \& National Farmers Union. (2019). Tackling the farm crisis and the climate crisis: A transformative strategy for Canadian farms and food systems (discussion paper). Saskatoon, SK: NFU. https://www.nfu.ca/wpcontent/uploads/2019/12/Tackling-the-Farm-Crisis-and-the-Climate-Crisis-Final-with-covers.pdf 
Rice, K., Hiwi, B. T., Zwarenstein, M., Lavallee, B., Barre, D. E., \& Harris, S. B. (2016). Best practices for the prevention and management of diabetes and obesity-related chronic disease among Indigenous peoples in Canada: A review. Canadian Journal of Diabetes, 40(3), 216-225. https://doi.org/10.1016/j.jcjd.2015.10.007

Riches, G. (2020). How food banks prop up a broken system. Vancouver, BC: The Tyee [Online news magazine]. https://thetyee.ca/Opinion/2020/04/22/Food-Banks-Prop-Broken-System/

Riddell, C. (2004). Union certification success under voting versus card-check procedures: Evidence from British Columbia, 1978-1998. Industrial and Labor Relations Review, 57(4), 493-517. https://doi.org/10.2307/4126680

Rideout, K., Riches, G., Ostry, A., Buckingham, D., \& MacRae, R. (2007). Bringing home the right to food in Canada: Challenges and possibilities for achieving food security. Public Health Nutrition, 10(6), 566-573. https://doi.org/10.1017/S1368980007246622

Robin, T., Dennis, M. K., \& Hart, M. A. (2020). Feeding Indigenous people in Canada. International Social Work. https://doi.org/10.1177/0020872820916218

Roman-Alcalá, A. (2018). (Relative) autonomism, policy currents and the politics of mobilisation for food sovereignty in the United States: The case of Occupy the Farm. Local Environment, 23(6), 619-634. https://doi.org/10.1080/13549839.2018.1456516

Roman-Alcalá, A. (2020, June 26). We can build a better food system through mutual aid (Op-ed article). Civil Eats. https://civileats.com/2020/06/26/op-ed-we-can-build-a-better-food-system-through-mutual-aid/

Schenk, C. (2014). Unions and democracy. Ottawa: Canadian Centre for Policy Alternatives, National Office. https://www.policyalternatives.ca/publications/reports/unions-and-democracy

Schiavoni, C. M. (2017). The contested terrain of food sovereignty construction: Toward a historical, relational and interactive approach. Journal of Peasant Studies, 44(1), 1-32. https://doi.org/10.1080/03066150.2016.1234455

Scialabba, N. (2015). Food wastage footprint \& climate change. Rome: Food and Agriculture Organization of the United Nations (FAO). http://www.fao.org/3/a-bb144e.pdf

Scott, D. N., \& Boisselle, A. (2019). If there can only be 'one law', it must be treaty law. Learning from Kanawayandan D'aaki. University of New Brunswick Law Review. Advance online publication. https://doi.org/10.2139/ssrn.3410499

Shattuck, A. (2020). Toxic uncertainties and epistemic emergence: Understanding pesticides and health in Lao PDR. Annals of the American Association of Geographers, 111(1), 216-230. https://doi.org/10.1080/24694452.2020.1761285

Skye, C. (2020, May 12). Colonialism of the curve: Indigenous communities \& bad Covid data. Toronto: Yellowhead Institute, Ryerson University. https://yellowheadinstitute.org/2020/05/12/colonialism-of-the-curve-indigenouscommunities-and-bad-covid-data/

Smith, L. T. (2012). Decolonizing methodologies: Research and Indigenous peoples (Second ed.). London: Zed Books.

Standing Committee on Indigenous and Northern Affairs. (2018). Indigenous land rights: Towards respect and implementation (12 $2^{\text {th }}$ Report). Ottawa: Proceedings of the House of Commons and Its Committees. https://www.ourcommons.ca/Content/Committee/421/INAN/Reports/RP9684841/inanrp12/inanrp12-e.pdf

Starblanket, G., \& Hunt, D. (2020). Covid-19, the numbered treaties \& the politics of life. Toronto: Yellowhead Institute, Ryerson University. https://yellowheadinstitute.org/covid-19-treaties/

Statistics Canada. (2020). Food insecurity during the COVID-19 pandemic, May 2020. Ottawa: Statistics Canada. https://www150.statcan.gc.ca/n1/pub/45-28-0001/2020001/article/00039-eng.htm

Stefan, N., Birkenfeld, A. L., Schulze, M. B., \& Ludwig, D. S. (2020). Obesity and impaired metabolic health in patients with COVID-19 [Comment]. Nature Reviews Endocrinology, 16(7), 341-342. https://doi.org/10.1038/s41574-020-0364-6

Stirling, A. (2009). Direction, distribution and diversity! Pluralising progress in innovation, sustainability and development (Working paper No. 32). Sussex, UK: STEPS Centre, University of Sussex. https://steps-centre.org/publication/directiondistribution-and-diversity-pluralising-progress-in-innovation-sustainability-and-development/

Stoddart, M. C. J., Tindall, D. B., \& Greenfield, K. L. (2012). “Governments have the power”? Interpretations of climate change responsibility and solutions among Canadian environmentalists. Organization \& Environment, 25(1), 39-58. https://doi.org/10.1177/1086026612436979 
Tarasuk, V. (2017). Implications of a basic income guarantee for household food insecurity (Basic Income Guarantee Series, Research Report No. 24). Thunder Bay, ON: Northern Policy Institute. https://proof.utoronto.ca/wp-content/uploads/2017/06/Paper-Tarasuk-BIG-EN-17.06.13-1712.pdf

Tarasuk, V., \& Mitchell, A. (2020). Household food insecurity in Canada, 2017-18. Toronto: Research to Identify Policy Options to Reduce Food Insecurity (PROOF). https://proof.utoronto.ca/resources/proof-annual-reports/household-food-insecurity-in-canada-2017-2018/

Tilman, D., \& Clark, M. (2014). Global diets link environmental sustainability and human health. Nature, 515(7528), 518522. https://doi.org/10.1038/nature13959

Torales, J., O’Higgins, M., Castaldelli-Maia, J. M., \& Ventriglio, A. (2020). The outbreak of COVID-19 coronavirus and its impact on global mental health. International Journal of Social Psychiatry, 66(4), 317-320. https://doi.org/10.1177/0020764020915212

Trauger, A. (2014). Toward a political geography of food sovereignty: Transforming territory, exchange and power in the liberal sovereign state. Journal of Peasant Studies, 41(6), 1131-1152. https://doi.org/10.1080/03066150.2014.937339

Trauger, A., Claeys, P., \& Desmarais, A. A. (2017). Can the revolution be institutionalized? In A. A. Desmarais, P. Claeys, \& A. Trauger (Eds.). Public policies for food sovereignty: Social movements and the state (pp. 1-16). Abingdon, UK, \& New York: Routledge.

Tuck, E., \& Yang, K. W. (2012). Decolonization is not a metaphor. Decolonization: Indigeneity, Education, \& Society, 1(1), 140. https://jps.library.utoronto.ca/index.php/des/article/view/18630

UN News. (2012). UN expert warns of global public health disaster caused by unhealthy foods. New York: UN News. https://news.un.org/en/story/2012/03/405632-un-expert-warns-global-public-health-disaster-caused-unhealthy$\underline{\text { foods }}$

University of Cambridge Judge Business School. (2020). The GDP@Risk over five years from COVID-19 could range from $\$ 3.3$ trillion to $\$ 82$ trillion. News \& Insight. Cambridge, UK: UCJBS, Centre for Risk Studies. https://insight.jbs.cam.ac.uk/2020/economic-impact/

Waldron, I. R. G. (2018). There's something in the water: Environmental racism in Indigenous \& Black communities. Halifax, NS, \& Winnipeg, MB: Fernwood.

Wallace, R. (2016). Big farms make big flu: Dispatches on influenza, agribusiness, and the nature of science. New York: Monthly Review Press.

Wallace, R., Liebman, A., Chaves, L. F., \& Wallace, R. (2020). COVID-19 and circuits of capital: New York to China and back. Monthly Review, 72(1), 1-15. https://doi.org/10.14452/MR-072-01-2020-05 1

Waziyatawin. (2012). The paradox of Indigenous resurgence at the end of empire. Decolonization: Indigeneity, Education \& Society, 1(1), 68-85. https://ips.library.utoronto.ca/index.php/des/article/download/18629/15553/

Weiler, A. M., McLaughlin, J., \& Cole, D. C. (2017). Food security at whose expense? A critique of the Canadian temporary farm labour migration regime and proposals for change. International Migration, 55(4), 48-63. https://doi.org/10.1111/imig.12342

White, M., Nieto, C. and Barquera, S. (2020) Good deeds and cheap marketing: The food industry in the time of COVID-19. Obesity, 28(9), 1578-1579. https://doi.org/10.1002/oby.22910

Whitmee, S., Haines, A., Beyrer, C., Boltz, F., Capon, A. G., De Souza Dias, B. F., .. Yach, D. (2015). Safeguarding human health in the Anthropocene epoch: Report of The Rockefeller Foundation-Lancet Commission on planetary health. The Lancet, 386(10007), 1973-2028. https://doi.org/10.1016/S0140-6736(15)60901-1

Willett, W., Rockström, J., Loken, B., Springmann, M., Lang, T., Vermeulen, S., .. Murray, C. J. L. (2019). Food in the Anthropocene: The EAT-Lancet Commission on healthy diets from sustainable food systems. The Lancet, 393(10170), 447-492. https://doi.org/10.1016/s0140-6736(18)31788-4

Willow, A. (2016) Indigenous extrACTIVISM in Boreal Canada: Colonial legacies, contemporary struggles and sovereign futures. Humanities, 5(3), 55, 1-15. https://doi.org/10.3390/h5030055

Wilson, N. J., Harris, L. M., Joseph-Rear, A., Beaumont, J., \& Satterfield, T. (2019). Water is medicine: Reimagining water security through Tr'ondëk Hwëch'in relationships to treated and traditional water sources in Yukon, Canada. Water, 11(3), 624, 1-19. https://doi.org/10.3390/w11030624 
Wilson, S. (2008). Research is ceremony: Indigenous research methods. Halifax, NS, \& Winnipeg, MB: Fernwood.

Wittman, H. (2009). Reworking the metabolic rift: La Vía Campesina, agrarian citizenship, and food sovereignty. Journal of Peasant Studies, 36(4), 805-826. https://doi.org/10.1080/03066150903353991

Wittman, H. (2015). From protest to policy: The challenges of institutionalizing food sovereignty. Canadian Food Studies, 2(2), 174-182. https://doi.org/10.15353/cfs-rcea.v2i2.99

Wittman, H., Dennis, J., \& Pritchard, H. (2017). Beyond the market? New agrarianism and cooperative farmland access in North America. Journal of Rural Studies, 53, 303-316. https://doi.org/10.1016/j.jrurstud.2017.03.007

Wolfe, P. (2006). Settler colonialism and the elimination of the native. Journal of Genocide Research, 8(4), 387-409. https://doi.org/10.1080/14623520601056240

World Food Programme. (2020, April 21). COVID-19 will double the number of people facing food crises unless swift action is taken (News release). Rome: World Food Programme, United Nations.

https://www.wfp.org/news/covid-19-will-double-number-people-facing-food-crises-unless-swift-action-taken

Wright, E. O. (2010). Envisioning real utopias. London, UK: Verso Books. 